these conflicting findings it would appear premature to assume the existence of a short-term visual storage mechanism, into which information may be read, stored, and subsequently erased, until considerably further research is carried out.

\section{References}

AVERBACH, E., \& CORIELL, A. S. Short-term memory in vision. Bell Syst. tech. J., 1961, 40, 309-328.

ERIKSEN, C. W., \& COLLINS, J. F. Backward masking in vision. Psychon. Sci., 1964, 1, 101-102.
ERIKSEN, C. W., \& STEFFY, R. A. Short-term memory and retroactive interference in visual perception. J. exp. Psychol., in press.

\section{Notes}

1. This study was performed by the four junior authors as part of a class project in a graduate Research Methods course given by the senior author. 2 . The authors would like to express their deep appreciation to Dr. C. W. Eriksen who made available to them a pre-publication draft of this article.

\title{
Sex differences in learning
}

\section{Frances B. Eisenman and Russell Eisenman}

UNIVERSITY OF GEORGIA

\begin{abstract}
Archer (1960) found some consonant-vowel-consonant trigrams more meaningful to males, some more so to females, and others neutral in meaningfulness. In an experiment, Archer, Cejka, \& Thompson (1961) found both males and females learned the male list quickest. The present study was a replication of the Archer, Cejka, and Thompson study, and while the results of our study were negative, the trends were in the predicted direction.
\end{abstract}

In a monograph published by Archer (1960) it is revealed that of all possible consonant-vowel-consonant trigrams, some are more meaningful to males, some are more meaningful to females, and others are neutral in meaningfulness. Since speed of learning was expected to be related to meaningfulness, Archer et al. (1961) hypothesized that males would learn the socalled male list quickest, and females the so-called female list. Their study provided only partial support for this hypothesis, both males and females learned the male list significantly faster. The present study was performed as a partial replication.

Archer et al. (1961) had a male experimenter test six males and six females; and, a female experimenter likewise tested six males and six females. They found that women learned faster as a result of being tested by a male experimenter. Consequently, our replication employed only a female experimenter.

The earlier study used psychology students, and presented the stimuli on a strip film projector. Our

Table 1. Mean Number of Trials Required for Male and Female Ss to Learn Each List

Male List Female List Neutral List

$\begin{array}{rrrr}\text { Mean } & 16.17 & 18.83 & 16.67 \\ \text { Males } \begin{array}{r}\text { S. D. } \\ \text { Mean }\end{array} & 5.08 & 6.72 & 6.62 \\ \begin{array}{c}\text { Females } \\ \text { S. D. }\end{array} & 8.94 & 6.917 & 12.50 \\ \end{array}$

study employed a memory drum, so we used nonpsychology students who were unacquainted with this apparatus. In all other respects a faithful replication was attempted.

The results with our twelve undergraduate subjects are shown in Table 1 . Our replication does not support the earlier study, since both inspection of the data visually and via $t$ tests show not a single significant difference.

There are, however, some interesting trends. As in the previous study, the results are more clear-cut with males, since they did learn the male list fastest, and the female list slowest, even though the differences are small. With the females, as in the earlier investigation, their results deviate more than the males from the predicted direction. Our female undergraduates learned the neutral list in the fewest number of trials.

If the neutral list is ignored, the results with the females are congruent with the results we obtained with males: both learn their own-sex list in the fewest trials, and take more trials to learn the oppositesex list.

While this study does not clearly support the earlier investigation, the fact that the trends are mostly in the predicted directions can be taken as tentative support. Further, it again appears that female subjects were more deviant from the predicted hypothesis, even though our replication omitted the male experimenter which had affected the results of the previous research.

This present study serves to point up how important it is to consider the sex of the subjects. Who knows how much earlier research produced negative or misleading results solely because of a failure to consider the different results which the two sexes may have yielded.

\section{References}

ARCHER, E. J. A re-evaluation of the meaningfulness of all possible CVC trigrams. Psychol. Monogr., 1960, 74, No. 10 (Whole No. 497).

ARCHER, E. J., CEJKA, J. E., \& THOMPSON, C. P. Serial-trigram learning as a function of differential meaningfulness and sex of subjects and experimenters. Canad. J. Psychol., 1961, 15, 148-153. 